\title{
Komposisi Jenis Kepiting Ocypodidae (Dekapoda: Brachyura) di Ekosistem Mangrove dan Estuari, TN Ujung Kulon
}

\section{Crabs Species Composition of Ocypodidae (Decapoda: Brachyura) in Mangrove and Estuari Ecosystems in Ujung Kulon National Park}

\section{Dewi Citra Murniati}

Bidang Zoologi, Pusat Penelitian Biologi, LIPI

Jl. Raya Jakarta-Bogor KM 46 Cibinong 16911

E-mail: citra_bio@yahoo.com

\begin{abstract}
Mangrove and estuary ecosystems are important components of the intertidal area which is the habitat of Ocypodid crabs. The study of Ocypodid crabs in Ujung Kulon National Park is still limited, while its habitat is decreasing. This study was conducted to explore the Ocypodid crabs (Brachyura: Ocypodidae) composition in mangrove and estuary ecosystems in Ujung Kulon National Park. Crabs species collection was carried out in Legon Cibariang, Panaitan Island and Cikawung, Ujung Kulon National Park. Four species of Ocypodid crabs, Ocypode ceratophthalma (Pallas, 1772), Uca annulipes (H. Milne Edwards, 1837), U. coarctata (H. Milne Edwards, 1852) and $U$. triangularis (A. Milne Edwards, 1873) were successfully collected from mangrove and estuary ecosystems. The species composition of Ocypodidae in Cikawung were more various than in Legon Cibariang.
\end{abstract}

Key words: Crabs, Ocypodidae, Ujung Kulon

Abstrak

Ekosistem mangrove dan estuari merupakan komponen penting dari area intertidal yang merupakan habitat kepiting Ocypodid. Saat ini, penelitian mengenai kepiting Ocypodid di TN Ujung Kulon masih sangat sedikit sedangkan habitatnya terus mengalami penyusutan. Penelitian ini dilakukan untuk menetukan komposisi jenis kepiting Ocypodidae (Brachyura: Ocypodidae) di ekosistem mangrove dan estuari Taman Nasional Ujung Kulon. Koleksi kepiting dilakukan di Legon Cibariang, Pulau Panaitan dan Cikawung, TN Ujung Kulon. Empat jenis kepiting Ocypodid yaitu Ocypode ceratophthalma (Pallas, 1772), Uca annulipes (H. Milne Edwards, 1837), U. coarctata (H. Milne Edwards, 1852) dan $U$. triangularis (A. Milne Edwards, 1873), berhasil dikoleksi dari ekosistem mangrove dan estuari. Komposisi jenis Ocypodidae di Cikawung lebih bervariasi dibandingkan Legon Cibariang.

Kata kunci: Kepiting, Ocypodidae, Ujung Kulon

Diterima: 19 Oktober 2009, disetujui: 28 April 2010

\section{Pendahuluan}

Ekosistem mangrove dan estuari merupakan komponen penting di daerah pasang surut dan memiliki produktivitas yang tinggi (Rahawarin, 2005). Selain fungsi ekonomi, mangrove memiliki peran ekologi yang sangat penting. Vegetasi mangrove dapat melindungi garis pantai dari gelombang, angin, dan badai (Purnobasuki, 2004). Akar mangrove dapat menahan dan menstabilkan sedimen yang terbawa oleh arus sungai dan laut. Mangrove mendukung kehidupan fauna yang hidup di dalamnya melalui dua tahapan. Pertama sebagai tempat berlangsungnya siklus hidup berbagai jenis ikan, moluska dan krustasea. Kedua sebagai tempat masuknya berbagai materi organik yang membawa makanan yang dibutuhkan oleh fauna mangrove maupun fauna yang sedang bermigrasi (Giesen et al., 2007; Jupri, 2006). Fauna bentik yang umum dan paling banyak ditemukan dalam ekosistem mangrove adalah jenis-jenis dari kepiting (Brachyura, Decapoda) (Rahayu et al., 2002). 
Kepadatan individu kepiting dapat mencapai 70 $\mathrm{ind} / \mathrm{m}^{2}$ terutama untuk jenis-jenis yang hidup meliang seperti kepiting Ocypodid (Brachyura: Ocypodidae). Kepiting dari Famili Ocypodidae terdiri dari dua genus yaitu Ocypode dan Uca. Kepiting ini merupakan fauna khas ekosistem mangrove dan estuari. Keberadaannya merupakan indikasi kondisi lingkungan (Pratiwi, 2007).

Pulau Panaitan merupakan pulau besar yang dibatasi oleh Selat Sunda dan Selat Panaitan Pulau ini berjarak sekitar $10 \mathrm{~km}$ dari Semenanjung Ujung Kulon. Keragaman vegetasi di Pulau Panaitan tidak jauh berbeda dengan vegetasi di Semenanjung Ujung Kulon. Vegetasi mangrove di Semenanjung Ujung Kulon terdapat di Cikawung, Cilintang, dan Cigeunteur. Adapun vegetasi mangrove di Pulau Panaitan terdapat di Tanjung Parat, Legon Lentah, Legon Mandar dan Legon Cibariang. Penelitian mengenai fauna bentik di daerah pasang surut terutama jenis kepiting Famili Ocypodidae dari Pulau Panaitan dan Muara Sungai Cikawung, TN Ujung Kulon masih sangat minim. Sementara itu, proses perusakan hutan mangrove akibat akumulasi sampah dan peralihan fungsi hutan yang dapat mengganggu kehidupan fauna bentik terus berlangsung (Rahawarin, 2005). Kondisi ini dapat menyebabkan punahnya beberapa jenis kepiting, terutama pemakan deposit, tanpa diketahui lebih dulu jenis dan jumlahnya.

Penelitian ini bertujuan untuk menentukan komposisi jenis-jenis kepiting dari Famili Ocypodidae yang diperoleh dari salah satu ekosistem mangrove dan satu ekosistem estuari di kawasan TN Ujung Kulon dan Pulau Panaitan. Data hasil penelitian ini selanjutnya dapat digunakan sebagai penunjang untuk penelitian yang akan datang.

\section{Metode Penelitian}

Kepiting Ocypodidae dikoleksi dari dua lokasi mangrove dan estuari yaitu di Legon Cibariang (S 638'19,2” E 105²'12'56,0”), Pulau Panaitan (Gambar 1) dan Muara Sungai Cikawung (S 649'47,9” E 105²9'47,9”), TN Ujung Kulon (Gambar 2). Kegiatan koleksi dilakukan pada bulan Nopember 2008. Vegetasi mangrove di Cikawung lebih di dominasi oleh Acanthus ilicifolius, sedangkan mangrove di Legon Cibariang merupakan mangrove tua yang didominasi oleh Rhizophora mucronata. Legon Cibariang merupakan teluk yang menjorok cukup tajam ke daratan. Kepiting dikoleksi dengan cara menggali liang dengan menggunakan sekop kecil kemudian kepiting diambil langsung dengan tangan pada area $1 \mathrm{~m} \mathrm{x}$ $1 \mathrm{~m}$. Koleksi kepiting dilakukan pada tiga titik, yaitu jarak $0 \mathrm{~m}, 10 \mathrm{~m}$ dan $50 \mathrm{~m}$ tegak lurus garis pantai terhitung mulai dari surut terendah. Tiga plot ditentukan sejajar garis pantai pada masingmasing titik.

Materi hasil koleksi di fiksasi menggunakan alkohol secara bertahap kemudian di awetkan dengan alkohol $80 \%$ dan disimpan di Laboratarium Crustacea Museum Zoologicum Bogoriense, LIPI, Cibinong. Identifikasi jenis berdasarkan panduan Crane (1975), Poore (2004) dan George dan Jones (1982). Karakter kunci dalam identifikasi Uca spp adalah karapas, capit besar jantan dewasa, gonopod jantan dan gonopore betina. Morfologi kepiting diamati dan digambar dengan mikroskop stereo Nikon SMZ800 yang dihubungkan dengan kamera lucida. Pengamatan gonopore betina melalui beberapa tahapan yaitu, spesimen di pre-fiksasi dengan glutaraldehid, kemudian post-fiksasi dengan tannin-acid, dehidrasi dengan alkohol bertingkat dan dilakukan freeze dried. Spesimen yang kering dilapisi (coating) dengan emas dan diamati dengan Scanning Electron Microscope (SEM) Jeol JSM 5310LV.

\section{Hasil dan Pembahasan}

\section{Komposisi Jenis}

Empat jenis kepiting dari famili Ocypodidae berhasil dikoleksi dari dua ekosistem di Legon Cibariang, Pulau Panaitan dan Cikawung TN Ujung Kulon dengan komposisi yang berbeda (Tabel 1). Tiap-tiap jenis ini menempati area yang berbeda dengan tipe habitat yang berbeda pula. 


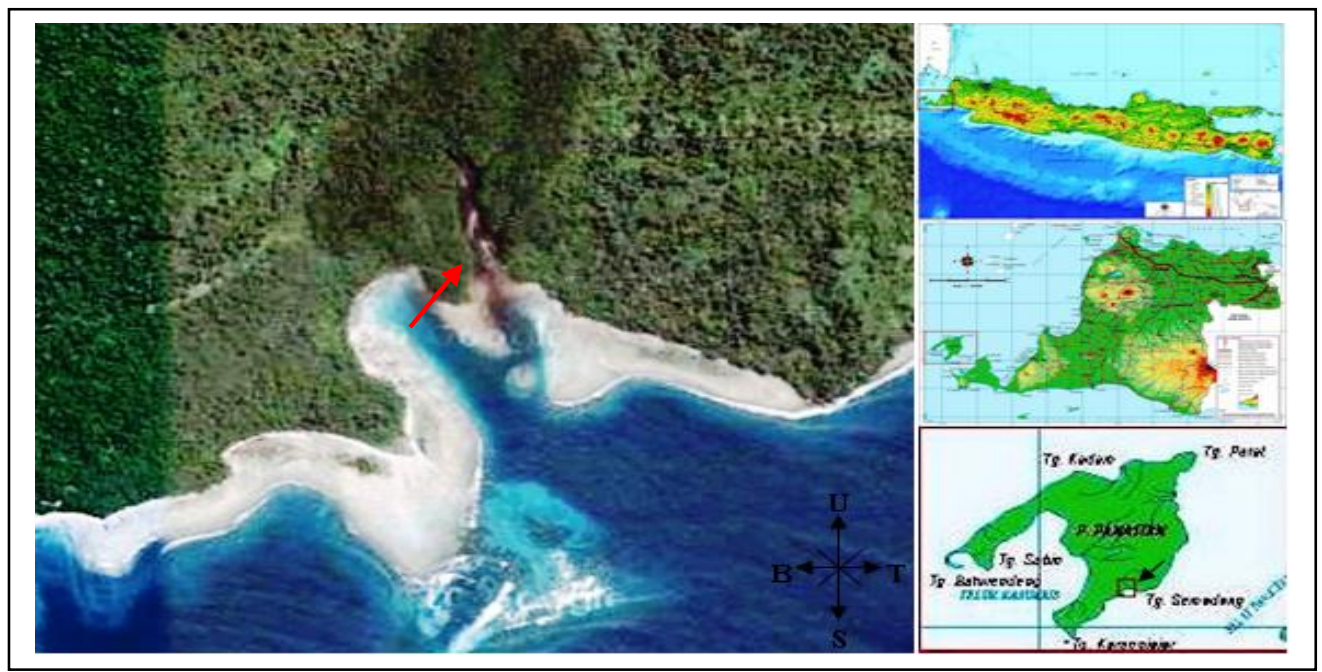

Gambar 1. Peta lokasi Legon Cibariang, Pulau Panaitan (Gambar ulang dari: www.maps. google.com,http://simpotda.bantenprov.go.id,http://geospasial.bnpb.go.id).

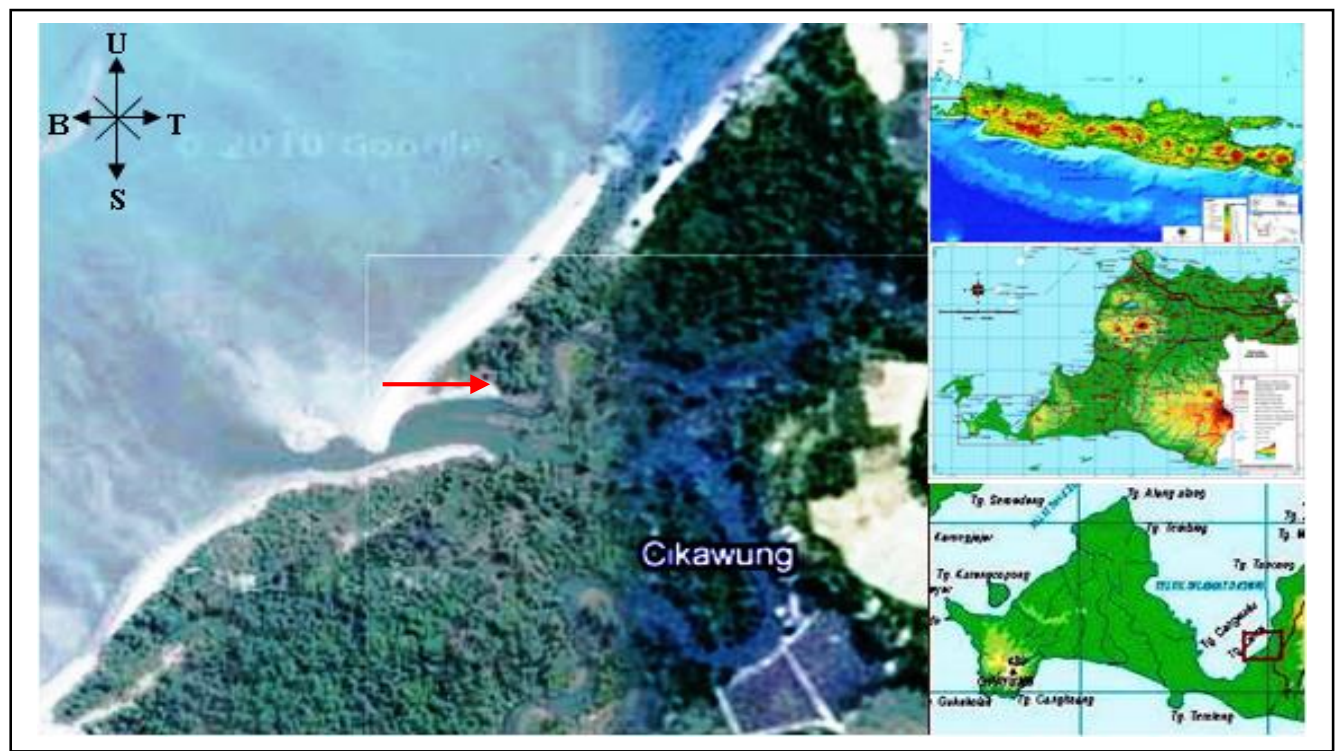

Gambar 2. Peta lokasi Cikawung, TN Ujung Kulon (Gambar ulang dari: www.maps. google.com, http://simpotda.bantenprov.go.id, http://geospasial.bnpb.go.id).

Tabel 1. Ocypodidae dari TN Ujung Kulon dan Pulau Panaitan (+ ada; - tidak ada).

\begin{tabular}{lcc}
\hline \hline \multirow{2}{*}{ Jenis } & & Lokasi \\
\cline { 2 - 3 } & Cikawung & Legon Cibariang \\
\hline \hline Ocypode ceratophthalma & + & + \\
Uca annulipes & + & - \\
U. coarctata & + & + \\
U. triangularis & + & + \\
\hline \hline
\end{tabular}




\section{Diskripsi Jenis}

\section{Ocypode ceratophthalma (Pallas, 1771)}

Karapas berbentuk persegi, berwarna abuabu putih. Pada jantan dewasa terjadi penandukan pada kornea mata. Capit tertutup oleh butir-butir dengan ukuran yang bervariasi. Ukuran capit kiri dan kanan tidak sama. Pada capit yang lebih besar terdapat stridulating ridge (organ sensorik penghasil suara) dan setae tumbuh di sepanjang salah satu sisi stridulating ridge. $O$. ceratophthalma hidup meliang di sepanjang bibir pantai berpasir. Gonopod jantan melengkung di bagian ujungnya, dan terdapat tonjolan terpulin pada $1 / 3$ bagian ujung. Umumnya aktif pada malam hari (Gambar 3A-B).

\section{Uca annulipes (H. Milne Edwards, 1837)}

Karapas halus, bagian frontal lebar, lekukan orbit tidak tajam. Tidak ada tonjolantonjolan di dasar orbit. Daktilus pada capit besar tidak dilengkapi alur memanjang dan halus (tanpa tonjolan). Daktilus dan polleks pipih, lebih panjang dibandingkan lengan. Gonopod jantan dengan ujung bercabang, satu bagian ujungnya melebar dan bagian lainnya lebih kecil dengan ujung meruncing. Gonopore betina dengan lukukan-lekukan yang sederhana, bagian tepi (bibir) tipis dan miring ke arah dalam. Hidup pada substrat pasir, dekat batas air sungai $(0 \mathrm{~m}-10 \mathrm{~m})$. Aktif pada saat air laut surut (Gambar 4A-D).

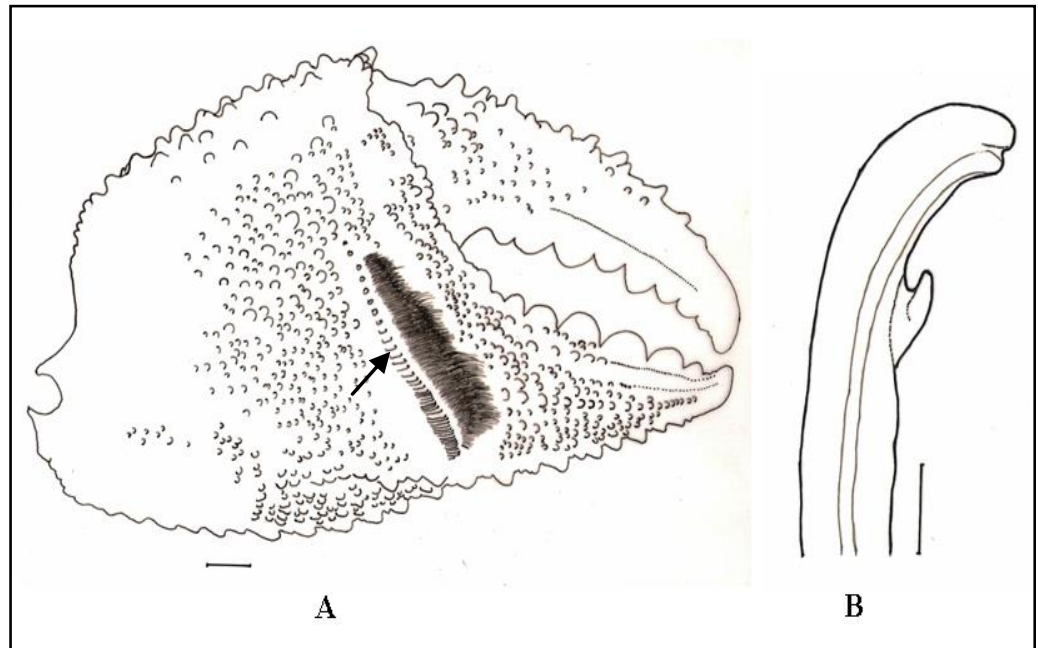

Gambar 3. Ocypode ceratophthalma. (A) capit dengan organ sensorik (tanda panah), (B) gonopod jantan. Skala: $1 \mathrm{~mm}$.

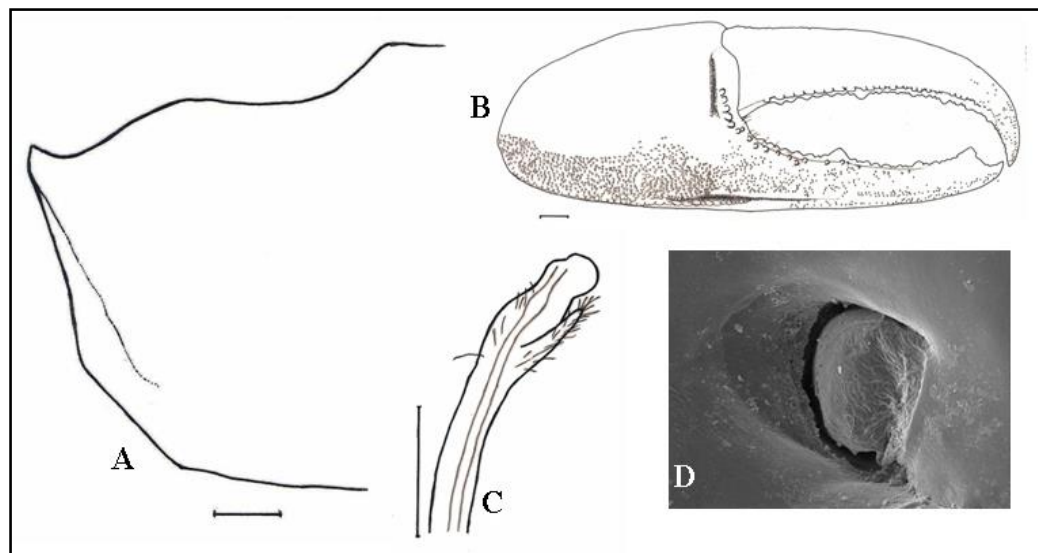

Gambar 4. Uca annulipes. (A) karapas, (B) capit besar jantan, (C) gonopod jantan, (D) gonopore betina. Skala: $1 \mathrm{~mm}$. 


\section{Uca coarctata (H. Milne Edwards, 1852)}

Karapas halus, bagian frontal sempit. Orbit pada karapas melekuk tajam. Pada dasar orbit terdapat butir-butir di belakang lekukan suborbital. Daktilus pada capit besar lebih panjang dibandingkan lengan, ditutupi oleh bintik-bintik mikroskopis, ujung daktilus berbentuk seperti kait, bagian permukaan dilengkapi alur yang panjang dan dilengkapi dengan tonjolan. Bagian lengan tertutup oleh butir-butir besar dan kecil. Gonopod jantan lurus dan ujungnya tidak bercabang. Gonopore betina dengan lekukan-lekukan yang membentuk batas yang jelas antara tepi bagian luar dan tepi bagian dalam. Jenis ini hidup pada substrat lumpur dekat dengan batas air sungai $(0 \mathrm{~m}-10 \mathrm{~m})$. Aktif pada saat air laut surut (Gambar 5A-D).

\section{Uca triangularis (A. Milne Edwards, 1873)}

Karapas halus, bagian frontal lebar, orbit melekuk tajam; dasar orbit dilengkapi dengan tonjolan-tonjolan. Pada capit jantan daktilus lebih panjang dibandingkan lengannya, bagian lengan terdapat tonjolan-tonjolan mikroskopis. Gonopod jantan melengkung dengan ujung meruncing, terbelah dan tidak bercabang. Tepi gonopore betina membentuk lekukan bergelombang. Hidup pada substrat lumpur halus dengan kadar air yang cukup tinggi. Umumnya meliang di antara akar-akar pohon ditepi sungai $(0 \mathrm{~m})$ hingga jarak $50 \mathrm{~m}$ dari sungai. Kepiting ini mudah dikenali di antara substrat lumpur yang hitam, bahkan pada fase juvenilnya, karena karapasnya yang berwarna putih polos dan kaki jalan bercorak garis-garis abu-abu dan putih (Gambar 6A-D).

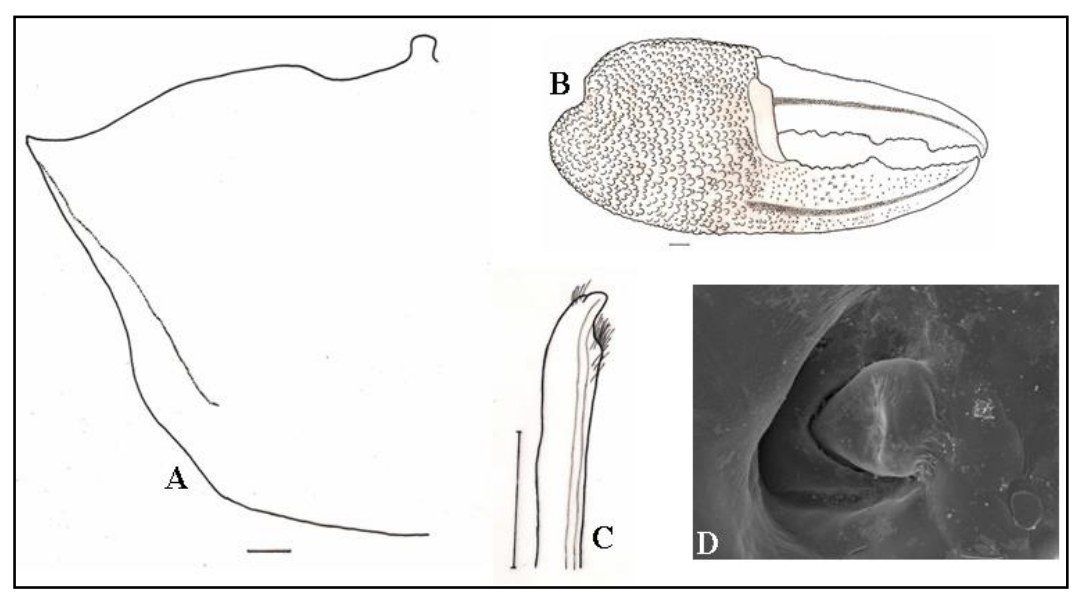

Gambar 5. Uca coarctata. (A) karapas, (B) capit besar jantan, (c) gonopod jantan, (D) gonopore betina. Skala: $1 \mathrm{~mm}$.

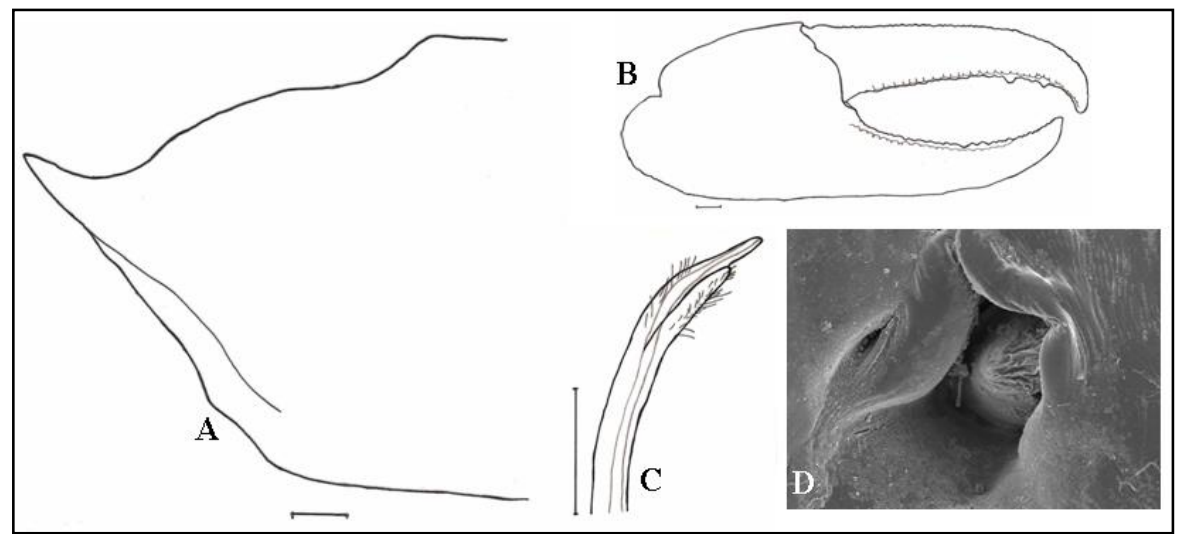

Gambar 6. Uca triangularis. (A) karapas, (B) capit besar jantan, (C) gonopod jantan, (D) gonopore betina. Skala: $1 \mathrm{~mm}$. 


\section{Habitat dan Kelimpahan Jenis}

Substrat hutan mangrove di Legon Cibariang sebagian besar adalah lumpur, jenis kepiting yang ditemukan hingga jarak $50 \mathrm{~m}$ dari batas air hanya $U$. coarctata dan $U$. triangularis. Adapun di Cikawung komposisi substrat lebih bervariasi yaitu substrat lumpur dan pasir sehingga komposisi jenis kepiting Ocypodid lebih bervariasi. Dua jenis Uca yang ditemukan di substrat lumpur yaitu $U$. coarctata dan $U$. triangularis. Kedua jenis kepiting ini dapat menempati habitat yang sama namun masingmasing memiliki perilaku yang berbeda sehingga akan menempati relung ekologi (niche) yang berbeda (Pratiwi, 2007). U. coarctata di temukan di area terbuka, agak jauh dari tumbuhnya vegetasi mangrove, sedangkan $U$. triangularis membuat liang di antara akar mangrove.

Area mangrove di Cikawung telah banyak mengalami perubahan fungsi menjadi lahan perkebunan komersil. Namun hal ini tidak banyak memengaruhi komposisi dan populasi kepiting Ocypodid terutama Uca spp. karena suplai materi organik yang terbawa aliran sungai dan pasang surut air laut cukup banyak. Selain itu salinitas air di Cikawung juga lebih rendah karena adanya masukan air sungai. Adapun Legon Cibariang hanya berupa teluk dan hampir tidak ada masukan air sungai pada lokasi ini. Hasil penelitian Crane (1975) menyebutkan bahwa Uca spp. lebih toleran terhadap salinitas rendah dibandingkan pada salinitas tinggi. Kisaran salinitas air laut untuk kehidupan $U c a$ spp adalah 25-30\%.

Vegetasi mangrove di Cikawung jauh lebih sedikit dibandingkan Legon Cibariang. Area Cikawung yang terbuka menyebabkan substrat terpapar langsung oleh cahaya matahari. Akibat tingginya intensitas cahaya matahari menyebabkan suhu permukaan sedimen di daerah ini menjadi lebih tinggi dibandingkan Legon Cibariang. Kisaran suhu di Cikawung yaitu $28^{\circ} \mathrm{C}-29^{\circ} \mathrm{C}$, sedangkan di Legon Cibariang yaitu $27^{\circ} \mathrm{C}$. Kisaran suhu ini masih cukup baik bagi kehidupan kepiting di area mangrove. Uca annulipes dapat bertahan hidup pada suhu maksimum $34^{\circ} \mathrm{C}$ (Crane, 1975).

Ocypode ceratophthalma umum ditemukan di sepanjang bibir pantai daerah tropis (Poore, 2004). Namun kondisi fisik pantai sangat mempengaruhi populasi jenis ini. Hasil survey menunjukkan bahwa populasi $O$. ceratophthalma di Cikawung lebih besar dibandingkan di Legon Cibariang. Hal ini disebabkan oleh batas area antara pasang tertinggi dan surut terendah di Cikawung jauh lebih besar dibandingkan dengan Legon Cibariang. Selain itu bibir pantai Legon Cibariang sebagian besar telah tertutup oleh tumpukan sampah organik dan anorganik yang terbawa arus sehingga habitat yang menyediakan makanan bagi $O$. ceratophthalma di lokasi ini semakin menyusut. Hal ini sesuai dengan beberapa penelitian yang menyebutkan bahwa keberadaan genus Ocypode sangat dipengaruhi beberapa faktor lingkungan seperti ukuran partikel pasir, kelembaban substrat, posisi zona pasang surut, derajat kemiringan zona pasang surut, ketersediaan makanan dan musim (Martin, 2006; Tureli et al., 2009).

Penelitian yang dilakukan oleh Lim et al., (2007) menunjukkan bahwa komposisi sedimen adalah faktor penting yang memengaruhi kelimpahan dan sebaran kepiting sehingga jenis kepiting yang ditemukan pada substrat lumpur berbeda dengan jenis yang hidup pada substrat pasir. O. ceratophthalma dan Uca annulipes hidup pada substrat pasir, sedangkan $U$. coarctata dan $U$. triangularis hidup pada substrat lumpur. O. ceratophthalma dan Uca spp. merupakan jenis kepiting pemakan deposit di permukaan substrat sehingga perbedaan habitat dapat diketahui dengan perbedaan morfologi maksilliped sebagai alat makan (Bezerra et al., 2006). Crane (1975) dan Lim (2005) menyebutkan bahwa jenis Uca spp yang hidup pada substrat pasir memiliki lebih banyak spoon tiped setae pada maksillipednya. Adapun Rosenberg (2001) menemukan bahwa jenis yang hidup pada substrat pasir memiliki ukuran maksilliped ketiga yang lebih lebar dibandingkan dengan jenis yang hidup pada substrat lumpur.

Siklus hidup kepiting Ocypodid melalui beberapa fase yaitu larva zoea, megalopa, juvenil dan dewasa. Fase larva zoea dan megalopa merupakan fase planktonik yang berlangsung di perairan estuari. Kondisi fisik dan kimia perairan merupakan faktor penting dalam fase ini. Salinitas air laut di Cikawung adalah 29\%o dan 
Legon Cibariang adalah 30\%o. Menurut Rabalais dan Cameron (1983), kisaran salinitas yang baik untuk kehidupan larva zoea dan megalopa adalah 15-30\%o. Struktur habitat yang kompleks dengan adanya vegetasi (mangrove, lamun dan makroalga) di perairan estuari dapat meningkatkan kemampuan bertahan hidup krustasea planktonik (Correa dan Uieda, 2008; Glancy et al., 2003). Habitat yang kompleks dapat menambah jumlah relung ekologi (niche) bagi koloni plankton dan mengurangi ancaman predasi. Kandungan nutrien dan oksigen yang cukup, serta tidak adanya polusi di perairan juga memberikan keuntungan bagi kelangsungan hidup fauna planktonik. Sebaliknya nutrisi berlebih dan hypoxia, ataupun nutrisi yang sangat minim dan anoxia dapat menyebabkan kematian fauna akuatik (Breitburg, 2002).

Fase juvenil hingga dewasa berlangsung di darat dalam hutan mangrove dan sepanjang area intertidal yang dipengaruhi pasang surut. Keanekaragaman kepiting pemakan deposit pada fase ini sangat dipengaruhi oleh kandungan materi organik dalam substrat (Ravara et al., 2000). Kandungan materi organik dalam substrat mendukung pertumbuhan kepiting baik secara individu maupun populasi (Benetti et al., 2004). Selain itu, minimnya polusi bahan kimia dan bioassay yang berpotensi racun memberikan peluang besar bagi kepiting untuk hidup dan berkembang biak (Pratiwi, 2007).

Secara umum, keberadaan kepiting Ocypodid dalam suatu ekosistem dapat dijadikan sebagai indikator kondisi lingungan karena kepiting ini memiliki hubungan timbal balik yang menguntungkan dengan lingkungannya. Komponen sedimen menyediakan partikel organik sebagai sumber makanan kepiting, sebaliknya kegiatan makan kepiting dapat memberi dampak positif bagi sedimen yaitu meningkatnya aerasi (sirkulasi udara) dalam sedimen dan penguraian nutrisi serta pembentukan mineral menjadi lebih cepat. Oleh karena itu semakin banyak jumlah jenis dan populasi kepiting Ocypodid, semakin baik kondisi lingkungan suatu ekosistem. Sebaliknya, dominansi satu jenis kepiting pada satu area menunjukkan kondisi lingkungan yang telah rusak (Ashton et al., 2003). Jumlah jenis Uca spp yang diperoleh pada penelitian ini lebih kecil dibandingkan dengan penelitian sebelumnya (Tabel 2). Namun, minimnya jumlah kepiting Ocypodid yang ditemukan pada penelitian ini tidak sepenuhnya akibat kondisi lingkungan yang kurang mendukung, tetapi karena metode dan waktu sampling yang kurang maksimal.

Tabel 2. Perbandingan jumlah jenis $U c a$ spp dari beberapa ekosistem mangrove di Indonesia.

\begin{tabular}{lcl}
\hline \hline \multicolumn{1}{c}{ Lokasi } & Jumlah Jenis Uca spp & \multicolumn{1}{c}{ Sumber } \\
\hline \hline TN Ujung Kulon & 3 & \\
Delta Mahakam, Kalimantan Timur & 7 & Pratiwi, 2007 \\
Pulau Kamora, Papua & 5 & Rahayu dan Setyadi, 2009 \\
Pulau Lombok & 2 & Matsuura et al., 2000 \\
Segara-anakan, Cilacap & 8 & Sastranegara et al., 2003 \\
\hline \hline
\end{tabular}

\section{Simpulan dan Saran}

\section{Simpulan}

Empat jenis kepiting Ocypodidade yaitu Ocypode ceratophthalma (Pallas, 1772), Uca annulipes (H. Milne Edwards, 1837), $U$. coarctata (H. Milne Edwards, 1852) dan $U$. triangularis (A. Milne Edwards, !873) berhasil dikoleksi dari Legon Cibariang, Pulau Panaitan dan Cikawung, TN Ujung Kulon. Kepiting Ocypodid ini ditemukan pada habitat yang berbeda. Ocypode ceratophthalma dan Uca annulipes ditemukan pada substrat pasir, $U$. coarctata dan $U$. triangularis pada substrat lumpur. Ocypode ceratophthalma hanya ditemukan di Cikawung. Komposisi jenis Ocypodidae di Cikawung lebih bervariasi dibandingkan Legon Cibariang.

\section{Saran}

Penelitian lanjutan perlu dilakukan minimal sekali dalam satu semester yang mewakili musim hujan dan musim kemarau. Data yang berkelanjutan dapat digunakan sebagai indikator perubahan kondisi lingkungan setiap tahunnya. Selanjutnya, data tahunan dapat digunakan sebagai bahan pertimbangan dalam 
kebijakan pengelolaan lingkungan terutama yang berstatus Taman Nasional, Cagar Alam ataupun Suaka Margasatwa. Penelitian lain untuk mendapatkan data kimia hasil kontaminasi lokal diperlukan untuk antisipasi kontaminasi lebih jauh. Uji bioassay pada wilayah ini perlu dilakukan agar keberadaan kontaminan dalam fauna bentik dapat diketahui.

\section{Ucapan Terima Kasih}

Penulis mengucapkan terima kasih kepada Proyek DIPA yang telah membiayai penelitian ini. Terima kasih juga kepada rekan-rekan KSK Mangrove, Kartika Dewi dan Yuni Apriyanti yang telah membantu pelaksanaan penelitian hingga terselesainya tulisan ini.

\section{Daftar Pustaka}

Ashton, E.C., Hogart, P.J. dan Macintosh, D.J. 2003. A Comparison of Brachyuran Crab Community Structure at Four Mangrove Location under Different Management System along the Melaka Straits-Andaman Sea Coast of Malaysia and Thailand. Estuaries, 26 (6): 1461-1471.

Benetti, A.S. dan Negreiros-Fransozo, M.L. 2004. Relative Growth of Uca burgersi (Crustacea: Ocypodidae) from Two Mangroves in the Southern Brazilian Coast. Iheringia, 94 (1): 67-72.

Bezerra, L.E., Carolina, B.D., Givanildo, X.A. dan Helena, M. 2006. Spatial Distribution of Fiddler Crab (Genus Uca) in a Tropical Mangrove of Northeast Brazil. Scientia Marina, 70 (4): 759-766.

Breitburg, D. 2002. Effects of Hypoxia, and the Balance between Hypoxia and Enrichment, on Coastal Fishes and Fisheries. Estuarios, 25 (4b): 767-781.

Correa, M.O.D.A. dan Uieda, V.S. 2004. Composition of the Aquatic Invertebrate Fauna Associated to the Mangrove Vegetation of a Coastal River, Analyzed through a Manipulative Experiment. Pan-American J. of Aquatic Sciences, 3 (1): 23-31.

Crane, J. 1975. Fiddler Crabs of the World, Ocypodidae: genus Uca. Princeton University Press, Princeton. 736 halaman.

George, R.W. dan Diana, S.J. 1982. A Revision of the Fiddler Crabs of Australia (Ocypodinae: Uca). Record of the Western Australian Museum Supll, 14: 1-99.
Giesen, W.S., Wulffraat, M. dan Scholten, L. 2007. Mangrove Guidebook for Southeast Asia; FAO and Wetlands International. Dharmasarn Co., Ltd. Thailand. Halaman: 34-36.

Glancy, T.P., Frazer, T.K., Cichra, C.E. dan Lindberg, W.J. 2003. Comparative Patterns of Occupancy by Decapod Crustaceans in Seagrass, Oyster, and Marsh-edge Habitats in a Northeast Gulf of Mexico Estuary. Estuarios, 26 (5): 1291-1301.

http://www.google.maps.com

http://simpotda.bantenprov.go.id,

http://geospasial.bnpb.go.id

Jupri, A. 2006. Inventarisasi Spesies Mangrove Di Teluk Kertasari, Sumbawa Barat. Biota, XI (3): 196-198.

Lim, S.S.L. 2005. A Comparative Study of some Mouthpart Adaptations of Uca annulipes ( $\mathrm{H}$. Milne Edwards, 1837) and $U$. vocans (Linnaeus, 1758) (Brachyura, Ocypodidae) in Relation to their Habitats. Crustaceana, 77 (10): 1245-1251.

Lim, S.S.L., Lee, P.S. dan Diong, C.H. 2007. Influence of Biotope Characteristics on the Distribution of Uca annulipes (H. Milne Edwards, 1837) and $U$. vocans (Linnaeus, 1758) (Crustacea: Brachyura: Ocypodidae) on Pulau Hantu Besar, Singapore. The Raffles Bulletin of Zoology, 53 (1): 111-114.

Martin, A.J. 2006. Resting traces of Ocypode quadrata Sssociated with Hydration and Respiration: Sapelo Island, Georgia, USA. Ichnos, 13 (1): 57-67.

Matsuura, K., Sumadiharga, O.K. dan Tsukamoto, K. 2000. Field Guide to Lombok Island; Identification Guide to Marine Organisms in Seagrass Beds of Lombok Island, Indonesia. Ocean Research Institute, University of Tokyo. Halaman: 87-88.

Poore, G.C.B. 2004. Marine Decapod Crustacea of Southern Australia; A Guide to Identification. CSHIRO Publishing, Victoria, Australia. Halaman: 21-22, 496-497.

Pratiwi, R. 2007. Jenis dan Sebaran Uca spp. (Crustacea: Decapoda: Ocypodidae) di Daerah Mangrove Delta Mahakam, Kalimantan Timur. $J$. Perikanan, 9 (2): 322-328.

Pratiwi, R. 2007. Studi Kepiting Mangrove di Delta Mahakam, Kalimantan Timur. Biota, 12 (2): 92-99.

Purnobasuki, H. 2004. Potensi Mangrove sebagai Tanaman Obat. Biota, IX (2): 125-126.

Rabalais, N.N. dan Cameron, J.N. 1983. Abbreviated Development of Uca subcylindrica (Stimpson, 1859) (Crustacea, Decapoda, Ocypodidae) Reared in the Laboratory. J. of Crustacean Biology, 3 (4): 519-541. 
Rahawarin, Y.Y. 2005. Komposisi Vegetasi Mangrove Di Muara Sungai Siganoi Sorong Selatan - Papua. Biota, X (3): 134-140.

Rahayu, D.L., Setyadi, G. dan Pribadi, R. 2002. Species Composition of Crabs (Anomura and Brachyura) of mangrove area in Kamora, Papua Province, Indonesia. JSPS-DGHE International Seminar Crustacean Fisheries.

Rahayu, D.L. dan Setyadi, G. 2009. Mangrove Estuary Crabs of the Mimika Region-Papua, Indonesia. PT Freeport Indonesia, Papua. Halaman: 104-109.

Ravara, S.C., Quintino, V. dan Rodrigues, A.M. 2000. Macrobenthic Community Characterisation of an Estuary from the Western Coast of Portugal (Sado Estuary) Prior to Dredging Operations. Bull. Instituto Espanol de Oceanografia, 17 (2): 179-190.
Rosenberg, M.S. 2001. The Comparative Claw Morphology, Phylogeny and Behavior of Fiddler Crabs (genus Uca): Dissertation for Doctor of Philosophy in Ecology \& Evolution. University of New York.

Sastranegara, M.H., Fermon, H. dan Muhlenberg, M. 2003. Diversity \& Abundance of Intertidal Crabs at the East Swamp Managed Areas in Segara Anakan Cilacap, Central Java, Indonesia. www.tropentag.de/2003/abstracts/full/171.pdf .

Tureli C., Duysak, O., Akamca, E. dan Kiyagi, V. 2009. Spatial Distribution and Activity Pattern of the Ghost Crab, Ocypode cursor (Linnaeus, 1758) in Yumurtalik Bay, North-Eastern Mediterranian-Turkey. J. of Animal \& Veterinary Advances, 8 (1): 165-171. 